\title{
Din Görevlilerinin Mesleki Doyum Düzeyleri Üzerine Bir Araştırma
}

DOI: 10.26466/opus.520597

\section{Emre Yilmaz}

*Dr. Öğr. Üyesi, Zonguldak Bülent Ecevit Üniversitesi, İlahiyat Fakültesi, Zonguldak / Türkiye E-Posta: eyilmaz2007@hotmail.com

ORCID: 0000-0002-1684-9821

\section{Öz}

Bu çalışma, Diyanet Işleri Başkanlığ lilerinin meslekle ilgili bir takım algılamaları ile meslekî doyum düzeyleri arasındaki ilişkiyi incelemek amacıyla tanımlayıcı olarak gerçekleştirilmiş bir saha araştırmasıdır. Araştırma 15 Ağustos 2018-15 Kasım 2018 tarihleri arasında gerçekleştirilmiştir. Araştırmanın evrenini, Bilecik il ve ilçe müftülüklerine bağlı merkez, köy ve kasabalarda kadrolu, sözleşmeli ve fahri statüde İmam-Hatip, Müezzin Kayyım ve Kur'an Kursu Öğreticisi olarak görev yapmakta olan toplam 465 din görevlisi oluşturmuştur. Araştırmada tarama modellerinden ilişkisel tarama modeli kullanılmıştır. Araştırma sonunda; din görevlilerinin mesleki doyum düzeylerinin; yapılan meslekten ve görev yapılan yerden duyulan memnuniyet, mesleği severek yapma, mesleki bilgi ve beceri açısından yeterli olma ve uygun şartların olması durumunda mesleği bırakma durumlarına göre anlamlılık değerlerinin $p<0,05$ olup; görev yerinden hiç memnun olmayan ve biraz memnun olanlarm mesleki doyum düzeylerinin görev yerinden memnun olanlara göre oldukça düşük düzeyde olduğu, mesleğinden kısmen memnun olanların mesleki doyum düzeylerinin mesleğinden memnun olanlara göre oldukça düşük düzeyde olduğu, mesleki bilgi ve beceri açısından yeterli olduğunu belirtenlerin mesleki doyum düzeyinin mesleki bilgi ve beceri açısından kendilerinin az yeterli ve yetersiz olduğunu belirtenlere göre daha yüksek düzeyde olduğu, mesleğini kısmen severek yapanların mesleki doyum düzeylerinin mesleğini tamamen severek yapanlara göre oldukça düşük düzeyde olduğu ve uygun şartların oluşması durumunda mesleğini bırakabileceğini belirtenlerin mesleki doyum düzeylerinin diğerlerine göre daha düşük düzeyde olduğ u tespit edilmiştir.

Anahtar Kelimeler: Diyanet Işsleri Başkanlığı, Din Görevlisi, Meslekî Doyum. 


\title{
A Research on the Occupational Job Satisfaction of Religious Officers
}

\begin{abstract}
This study is a descriptive field research conducted in order to examine the relationship between the professional perceptions of the religious officials working in the Bilecik Provincial and District Muftis Office. The study was conducted between 15 August 2018 and 15 November 2018. The universe of the research consisted of 465 religious officials, who were permanent, contracted and honorary status teachers of the Imam-Hatip, Muezzin Kayyim and Qur'an Courses in the centers, villages and towns connected to the Bilecik provincial and district muftis. The research was designed in descriptive survey and comparative relational screening models. At the end of the research; professional job satisfaction levels of religious officials; the satisfaction of the profession and the place of duty, the profession of doing the job, the professional knowledge and skills in terms of being adequate and in the case of appropriate conditions, according to the status of the occupation of the significance values of $p<0.05$; the job satisfaction levels of those who are not satisfied with the job place and who are slightly satisfied are quite low compared to those who are satisfied with the job place; the occupational job satisfaction levels of those who are partially satisfied are quite low compared to those who are satisfied with the profession; In terms of professional knowledge and skill, the level of satisfaction is higher than the ones who stated that they are less than adequate and inadequate; It was found to be at a lower level.
\end{abstract}

Keywords: Religious Affairs Directorate, Religious Officer, Professional Satisfaction.

OPUS (c) Uluslararası Toplum Araştırmaları Dergisi-International Journal of Society Researches ISSN:2528-9527 E-ISSN : 2528-9535

http://opusjournal.net 


\section{Giriş}

Kişinin ya da çalışanın işiyle ilgili tutumu (Piyal vd., 2002) olarak tanımlanan meslekî doyum, genel olarak, istekleri giderme ve ihtiyaçları tatmin açısından mevcut koşullarla yetinme ve hoşnut olma durumunu ifade etmektedir (Yelboğa, 2008). Başka bir deyişle, meslekî doyum, belli bir işi ya da mesleği icra eden kişilerin yaptıkları işle ilgili memnuniyetlerini ifade etmektedir (Mersin, 2007).

Mesleki doyum bireyin gündelik hayata yönelik tutumlarının şekillenmesinde önemli bir gerçektir. Bireylerin meslek hayatındaki tatmin düzeyleri, hem işteki başarıyı, hem de hayatlarının diğer alanlarını etkilemektedir.

Bu çalışma topluma din hizmeti sunan ve toplumun din öğretimi ihtiyacına cevap vermeye çalışan Diyanet İşleri Başkanlığı personelinin mesleki doyumuna ilişkin bilgiler elde etmek amacıyla yapılmış bir alan araştırmasidir.

Bilindiği üzere ülkemizde din hizmetleri ve yaygın din eğitimi görevini resmi olarak yürütmekle görevli kurum Diyanet İşleri Başkanlığı'dır. Başkanlık Kur'an Kursları ve bu kurslarda vazifeli Kur'an Kursu Öğreticileri vasıtasıyla yaygın din eğitimi faaliyetlerini, camiler ve camilerde görevli İmam-Hatip ve Müezzin-Kayyımlar vasıtasıyla da din hizmetleri görevini yerine getirmeye çalışmaktadır.

Diyanet İşleri Başkanlığı'nın yürütmekle yükümlü olduğu toplumu din konusunda aydınlatma görevini en iyi şekilde ifa edilebilmesi, yapılan işin hedeflenen amaca ulaşması, performans ve verimliliğin arttırılarak azami ölçüde verim sağlanması ve böylelikle kurumun başarısına doğrudan katkı sunulmasında; bu meslekte görev alan din görevlilerinin mesleğe yönelik tutumlarının, mesleklerine dair beklenti ve mesleğe dair yaşadıkları problemlerin tespit edilmesi ve böylece din görevlilerinin mesleki doyumlarını arttırıcı çalışmalar yapılmasının büyük ehemmiyeti bulunmaktadır. Bu doğrultuda bu çalışma, Diyanet İşleri Başkanlığı Bilecik il ve ilçe müftülükleri bünyesinde merkez, kasaba ve köylerde İmam-Hatip, Müezzin-Kayyım ve Kur'an Kursu Öğreticisi olarak görev yapan din görevlilerinin meslekten ve görev yerlerinden memnun olup-olmama, mesleği severek yapıp-yapmama, mesleki bilgi ve beceri açısından yeterli 
olup-olmama ve uygun şartların olması durumunda mesleği bırakıp-bırakmama durumları gibi meslekle ilgili bir takım algılamalarını ifade eden değişkenler ile "görevlinin din hizmetleri alanında yaptığ 1 işten istek ve ihtiyaçları bakımından hoşnut olması" (Kayıklık, 2008, s.35) olarak tanımlanan meslekî doyum düzeyleri arasındaki ilişkiyi incelemek amacıyla tanımlayıcı olarak gerçekleştirilmiş bir saha araştırmasıdır.

\section{Araştırma ve Yöntem}

\section{Araştırma Modeli}

Araştırmada betimsel tarama ve ilişkisel tarama modelleri tercih edilmiştir. Tarama modelleri geçmişte ya da halen var olan bir durumu var olduğu şekilde betimlemeyi amaçlayan araştırma yaklaşımlarıdır (Balcı, 2015, s.148; Özdemir, 2014, s.79; Büyüköztürk, 2008, s.19). Araştırmaya konu olan olay, birey ya da nesne, kendi koşulları içinde ve olduğu gibi tanımlanmaya çalışılır (Karasar, 2005). İlişkisel araştırmalar ise, değişkenler arasındaki ilişkiyi, ilişki testleri kullanarak ortaya çıkarmayı amaçlar (Balc1, 2015). Bu araştırma, din görevlilerinin meslekle ilgili bir takım algılamalarıyla ilgi bazı değişkenler ile meslekî doyum düzeylerini tespit etmeye çalışmasından dolayı tarama modelindedir. Bununla birlikte araştırma aynı zamanda din görevlilerinin meslekle ilgili bir takım algılamalarını ifade eden değişkenler ile meslekî doyum düzeyleri arasındaki ilişkiyi incelemesinden dolayı da ilişkisel modeldedir.

\section{Evren ve Örneklem}

Bilecik il ve ilçe müftülüklerine bağlı merkez, köy ve kasabalarda kadrolu, sözleşmeli ve fahri statüde İmam-Hatip, Müezzin Kayyım ve Kur'an Kursu Öğreticisi olarak görev yapmakta olan toplam 465 din görevlisi araştırmanın evrenini oluşturmuştur. Araştırmanın örneklemini ise, müftülüklerce din görevlilerine yönelik olarak her ay düzenlenen toplantılardan Ağustos, Eylül, Ekim ve Kasım aylarında gerçekleştirilen aylık mutat toplantılara izin ve raporlu olmaları sebebiyle katılmayan personel d1şında, toplantılarda hazır bulunan 433 din görevlisi oluşturmuştur. 


\section{Araştırmanın Hipotezleri}

1. Diyanet İşleri Başkanlığında din hizmetleri sınıfında çalışan personelin mesleki doyum düzeyi meslekten duyulan memnuniyet durumuna göre anlamlı farklılık gösterir. Mesleğinden kısmen memnun olanların mesleki doyum düzeyi mesleğinden memnun olanlara göre oldukça düşük düzeydedir.

2. Mesleki doyum düzeyi görev yerinden memnuniyet durumuna göre anlamlı farklılık gösterir. Görev yerinden hiç memnun olmayan ve biraz memnun olanların mesleki doyum düzeyi görev yerinden memnun olanlara göre oldukça düşük düzeydedir.

3. Mesleki doyum düzeyi mesleki bilgi ve beceri açısından yeterli olma durumuna göre anlamlı farklılık gösterir. Mesleki bilgi ve beceri açısından yeterli olduğunu belirtenlerin mesleki doyum düzeyi mesleki bilgi ve beceri açısından az yeterli ve yetersiz olduğunu belirtenlerden daha yüksek düzeydedir.

4. Mesleki doyum düzeyi mesleği severek yapma durumuna göre anlamlı farklılık gösterir. Mesleğini kısmen severek yapanların mesleki doyum düzeyi mesleğini tamamen severek yapanlara göre oldukça düşük düzeydedir.

5. Mesleki doyum düzeyi uygun şartların olması durumunda mesleği bırakma durumuna göre anlamlı farklılık gösterir. Uygun şartların oluşması durumunda mesleğini bırakabileceğini belirtenlerin mesleki doyum düzeyi diğerlerine göre daha düşük düzeydedir.

\section{Veri Toplama Aracı}

Tarama modellerinde veriler, genellikle gözlem, anket, görüşme veya test gibi bilgi toplama yolları ile elde edilir (Balcı, 2015, s.148; Özdemir, 2014, s.79; Büyüköztürk, 2008, s.19). Din görevlilerinin mesleki doyum düzeylerini tespit etmek amacıyla yapılan bu araştırmada nicel araştırma tekniklerinden anket kullanılmıştır. Araştırmada katılımcı grubun sosyo-demografik özelliklerine ilişkin bilgiler edinmek amacıyla demografik özellikler ve mesleğe dair algıları kapsayan bir "Kişisel Bilgiler Formu" ve din görevlilerinin yaptıkları işten memnun olup olmama (mesleki doyumu ve 
doyumsuzluğu) düzeylerini tespit etmek için, Yıldız Kuzgun, Seher A. Sevim ve Zeynep Hamamcı'nın herhangi bir işte çalışan bireylerin o mesleğin üyesi olmaktan ne derece mutlu olduklarını belirlemek amacıyla geliştirdikleri “Meslekî Doyum Ölçeği” kullanılmıştır (Kuzgun, Sevim, Hamamc1, 2005, ss.82-87).

\section{Mesleki Doyum Ölçeği ve Puanlaması}

Mesleki Doyum Ölçeği (MDÖ) herhangi bir işte çalışan bireylerin o mesleğin üyesi olmaktan ne derece mutlu olduklarını belirlemek amacıyla geliştirilmiştir (Kuzgun, Sevim, Hamamc1 2005, ss. 82-87). Alınan puanlar yüksek olduğunda bireyin mesleki doyumunun yüksek olduğu kabul edilir (Kuzgun ve Bacanlı, 2005, ss.84-85). Ölçek beşli Likert tipi 21 sorudan oluşmaktadır. Sorular kişilerin mesleki etkinliklerinin ilgi ve yeteneklerine uygunluğu, sorumluluk alma, gelişme ve ilerleme olanakları ile ilgilidir. Ölçekteki testten alınabilecek en düşük puan 21, en yüksek puan ise 105 'tir. Alınan puanlar yükseldikçe mesleki doyum yükselir. Puanların $25^{\prime}$ in altında olması düşük mesleki doyumunu, 26 ile 74 arasında olması normal mesleki doyumunu, 75'in üzerinde olması ise yüksek mesleki doyumunu ifade etmektedir.

\section{Mesleki Doyum Ölçeğine Ait Güvenilirlik Analizi}

Katılımcıların mesleki doyum düzeyini ölçmek için 21 maddeden oluşan Mesleki Doyum ölçeğinin analiz yapmaya uygun olup olmadığı, örneklem hacminin yeterli olup olmadığı ve verilerin rastgele dağılıp-dağılmadığının tespiti için Güvenilirlik Analizi kullanılmıştır.

Güvenilirlik analizi ölçmede kullanılan testlerin, anketlerin ya da ölçeklerin özelliklerini ve güvenilirliklerini değerlendirmek üzere geliştirilmiş bir yöntemdir.

Cronbach's Alfa ( $\alpha$ ) katsayısına bağlı olarak ölçeğin güvenilirliği aşağıdaki gibi yorumlanır.

- $0,00 \leq \alpha<0,40$ ise ölçek güvenilir değildir.

- $0,40 \leq \alpha<0,60$ ise ölçeğin güvenilirliği düşük

- $0,60 \leq \alpha<0,80$ ise ölçek oldukça güvenilir 
- $\quad 0,80 \leq \alpha<1,00$ ise ölçek yüksek derecede güvenilir bir ölçektir.

Ankette kullanılan ölçeğe ait güvenilirlik katsayıları aşağıdaki tabloda gösterilmiştir.

Tablo 1. Mesleki Doyum Ölçeğine Ait Güvenilirlik Analizi Sonuçları

\begin{tabular}{lcc}
\hline Ölçek & Cronbach's Alpha & Madde Sayısı \\
\hline Mesleki İş Doyumu & 0.900 & 21 \\
\hline
\end{tabular}

Mesleki doyum ölçeği için güvenilirlik katsayısı $\alpha=0,900$ bulunmuştur. Bu değer Meslekî Doyum Ölçeğinin geçerli ve yüksek derecede güvenilir, verilerin de analiz yapmaya uygun olduğunu göstermektedir. Saha araştırmamız sonucu ulaşılan veriler üzerinden Meslekî Doyum Ölçeğinin geçerlik ve güvenirlik çalışmaları sonucunda ulaştığımız bulguların, Kuzgun ve arkadaşlarının elde ettiği sonuçlarla yaklaşık aynı düzeyde olduğu görülmektedir (Kuzgun, Sevim, Hamamc1, 2005).

\section{Verilerin Toplanması}

Bu çalışmada, din görevlilerinin meslekî doyum düzeylerini tespit edebilmek amacıyla anket uygulaması yapılmıştır. Anketin uygulama aşaması geçilmeden önce ilgili resmi kurumlardan (Bilecik Valiliği, Bilecik İl Müftülüğü) gerekli resmi izinler alınmış ve araştırmanın anket uygulaması 15 Ağustos 2018-15 Kasım 2018 tarihleri arasında gerçekleştirilmiştir.

Diyanet İşleri Başkanlığına ait istatistiki verilerde 31.12.2017 itibariyle Bilecik il ve ilçe müftülüklerinde İmam-Hatip, Müezzin-Kayyım ve Kur'an Kursu Öğreticisi statüsünde 420'si kadrolu ve sözleşmeli 45'i ise fahri olmak üzere 465 personel mevcut olup aylık mutat toplantılara izin ve raporlu olmaları sebebiyle katılmayan personel dışında, toplantılarda hazır bulunan 433 personele anket uygulanmış, bütün anket formları teker teker incelenerek eksik olup olmadıkları kontrol edilmiş, ancak anket formlarından bazılarının eksik, bazılarının ise birden fazla şı işaretlenmiş 
olması sebebiyle değerlendirme dışı bırakılarak 419 form değerlendirmeye alınmıştır. Araştırma örnekleminin, evrenin yaklaşık \% 91'ini kapsaması, bulguların güvenirliliği açısından büyük önem arz etmektedir.

\section{Verilerin Analizi}

Araştırmada elde edilen verilerin istatistiksel analizinde SPSS (Statistical Package for Social Sciences) v22.0 paket programı kullanılmış, verilerin çözümlenmesinde ise frekans analizi, aritmetik ortalama, standart sapma, yüzde gibi betimsel istatistiklerden faydalanılmıştır. Araştırmada değiş̧kenler arası ilişkiyi ölçmek için ise Korelasyon Analizi kullanılmıştır. Araştırmaya katılanların mesleki doyum düzeylerinin mesleki bilgilerine göre farklılık gösterip göstermediği T (Student) ve F (Varyans) testleri ile test edilmiştir.

\section{Bulgular}

Araştırmanın bu bölümünde araştırmaya katılan katılımcıların kurumda yapmakta olduğu görev, çalıştı̆̆ı meslekten ve görev yapmakta olduğu yerden memnuniyet durumu, mesleğini severek yapıp-yapmama, mesleki bilgi ve beceri açısından kendilerini yeterli görüp-görmeme ve koşulların uygun olması durumunda mesleği bırakmak isteyip-istemediklerini tespit etmeye yönelik olarak kendilerine yöneltilen ölçek sorularına verdikleri yanıtlardan elde edilen bulgulara yer verilmiştir.

\section{Kişisel ve Meslekle İlgili Algılamalara ilişkin Bulgular}

Tablo 2. Kurumda Yapmakta Olduğunuz Görev

\begin{tabular}{lcc}
\hline Görev & Kişi Sayısı & Oran (\%) \\
\hline İmam-Hatip & 220 & 52.5 \\
Sözleşmeli İmam-Hatip & 26 & 6.2 \\
Vekil İmam-Hatip & 4 & 1.0 \\
Müezzin Kayyım & 52 & 12.4 \\
Kur'an Kursu Öğreticisi & 48 & 11.5 \\
Sözleşmeli Kur'an Kursu Öğreticisi & 7 & 1.7 \\
Fahri Kur'an Kursu Ö̆ğreticisi & 62 & 14.8 \\
Toplam & 419 & 100.0 \\
\hline
\end{tabular}


Araştırmaya katılanların \%52,5'i İmam-Hatip, \%14,8'i Fahri Kur'an Kursu Öğreticisi, \%12,4'ü Müezzin-Kayyım, \%11,5'i Kadrolu Kur'an Kursu Öğreticisi, \%6,2'si Sözleşmeli İmam-Hatip, \%1,7'si Sözleşmeli Kur'an Kursu Öğreticisi ve \%1'i ise Vekil İmam-Hatip olarak görev yapmakta olduklarını belirtmişlerdir.

Tablo 3. Görev Yapmakta Olduğunuz Yerden Memnuniyet Durumunuz

\begin{tabular}{lcc}
\hline Memnuniyet & Kişi Sayısı & Oran (\%) \\
\hline Hiç memnun değilim & 15 & 3.6 \\
Biraz memnunum & 134 & 32.0 \\
Çok memnunum & 270 & 64.4 \\
Toplam & 419 & 100.0 \\
\hline
\end{tabular}

Araştırmaya katılanların \%3,6'sı görev yaptığ 1 yerden hiç memnun değilken, \%32'si biraz memnun ve \%64,4'ü de çok memnun olduğunu belirtmektedir.

Tablo 4. Çalıştı̆̆ınız meslekten memnun musunuz?

\begin{tabular}{lcc}
\hline Memnuniyet Durumu & Kişi Sayısı & Oran (\%) \\
\hline Evet & 382 & 91.2 \\
Kismen & 33 & 7.9 \\
Hayır & 4 & 1.0 \\
Toplam & 419 & 100.0 \\
\hline
\end{tabular}

Araştırmaya katılanların \%91,2'si çalıştığı meslekten memnunken, $\% 7,9^{\prime}$ u kısmen memnun olduğunu, \%1'i de memnun olmadığını belirtmektedir.

Tablo 5. Mesleğginizi severek mi yapıyorsunuz?

\begin{tabular}{lcc}
\hline Meslek Sevgisi & Kişi Sayısı & Oran (\%) \\
\hline Evet & 392 & 93.6 \\
Hayır & 3 & 0.7 \\
Kismen & 24 & 5.7 \\
Toplam & 419 & 100.0 \\
\hline
\end{tabular}

Araştırmaya katılanların \%93,6'sı mesleğini severek yaptığını belirtirken, \%0,7'si mesleğini sevmeden yaptığını, \%5,7'si de kısmen severek yaptığını belirtmektedir. 
Tablo 6. Mesleki bilgi ve beceri açısından kendinizi yeterli görüyor musunuz?

\begin{tabular}{lcc}
\hline Yerlilik Durumu & Kişi Sayısı & Oran $\mathbf{( \% )}$ \\
\hline Tamamen yeterli & 63 & 15.0 \\
Yeterli & 227 & 54.2 \\
Kismen yeterli & 120 & 28.6 \\
Yetersiz & 9 & 2.1 \\
Toplam & 419 & 100.0 \\
\hline
\end{tabular}

Araştırmaya katılanların \%15'i mesleki bilgi ve beceri açısından kendisini tamamen yeterli görürken, $\% 54,2$ 'si yeterli, $\% 28,6$ 's1 kısmen yeterli görmekte, $\% 2,1^{\prime} i$ ise yetersiz görmektedir.

Tablo 7. Bugün koşullarınız uygun olsa bu mesleği bırakır ve başka bir kurumda çalışmak ister misiniz?

\begin{tabular}{lcc}
\hline Mesleği Bırakma Durumu & Kişi Sayısı & Oran (\%) \\
\hline Evet & 43 & 10.3 \\
Hayır & 327 & 78.0 \\
Kararsızım & 49 & 11.7 \\
Toplam & 419 & 100.0 \\
\hline
\end{tabular}

Araştırmaya katılanların \%10,3'ü koşulların uygun olması durumunda mesleğini bırakıp başka kurumda çalışmayı isterken, \%78'si ise istememektedir. Katılımcıların \%11,7'si ise bu duruma kararsız kalmıştır.

\section{Meslekle İlgili Algılamalar ile Meslekî Doyum Düzeyi Arasındaki İliş-} kiye Dair Bulgular

Çalışmanın bu kısmında, örneklemimizi oluşturan din görevlilerinin mesleki doyum düzeyleri ile meslekle ilgili bir takım algılamalarını ifade eden değişkenler arasındaki ilişkiyi tespit etmeye yönelik araştırma sonucunda ulaşılan bulgular tablolar halinde sunulmuştur.

Tablo 8. Mesleki Doyum Dïzeyinin Görev Yapılan Yerden Duyulan Memnuniyete Göre Farklılı̆̆ın Inceleyen F Testi Sonuçları

\begin{tabular}{llccccc}
$\begin{array}{l}\text { Öl- } \\
\text { çek/Bo- } \\
\text { yutlar }\end{array}$ & $\begin{array}{l}\text { Görev Yerinden } \\
\text { Memnuniyet }\end{array}$ & $\begin{array}{c}\text { Kişi } \\
\text { Sayısı }\end{array}$ & $\overline{\boldsymbol{X}}$ & $\begin{array}{c}\text { Std. } \\
\text { Sapma }\end{array}$ & $\mathbf{F}$ & $\mathbf{p}$ \\
\hline Mesleki & Hiç memnun değilim & 15 & 80.80 & 14.591 & & \\
Doyum & Biraz memnunum & 134 & 85.07 & 12.012 & $34.431^{*}$ & 0.001 \\
& Çok memnunum & 270 & 94.15 & 10.857 & & \\
\hline
\end{tabular}

${ }^{*} \mathrm{p}<0,05$ 
İş doyum düzeyinin görev yapılan yerden duyulan memnuniyete göre anlamlı farklılık gösterip göstermediğini test eden $F$ testi sonucuna göre anlamlılık değeri $\mathrm{p}<0,05$ bulunmuştur. Bu değere göre ortalamalar arasinda anlamlı fark vardır. Yani, mesleki doyum düzeyi görev yerinden memnuniyet durumuna göre anlamlı farklılık gösterir. Görev yerinden hiç memnun olmayan ve biraz memnun olanların mesleki doyum düzeyi görev yerinden memnun olanlara göre oldukça düşük düzeydedir.

Tablo 9. Mesleki Doyum Düzeyinin Mesleki Bilgi ve Beceri Açısından Yeterli Olma Durumuna Göre Farklılı̆̆ını İnceleyen F Testi Sonuçları

\begin{tabular}{llccccc}
\hline Ölçek/Boyutlar & Yeterlik Durumu & $\begin{array}{c}\text { Kişi } \\
\text { Sayıs }\end{array}$ & $\overline{\boldsymbol{X}}$ & $\begin{array}{c}\text { Std. } \\
\text { Sapma }\end{array}$ & $\mathbf{F}$ & $\mathbf{p}$ \\
\hline \multirow{3}{*}{ Mesleki Doyum } & Tamamen yeterli & 63 & 94.29 & 10.398 & & \\
& Yeterli & 227 & 92.55 & 11.510 & $13.665^{*}$ & 0.001 \\
& Kismen yeterli & 120 & 86.72 & 12.055 & & \\
& Yetersiz & 9 & 75.22 & 20.055 & & \\
\hline
\end{tabular}

${ }^{*} \mathrm{p}<0,05$

Tabloda din görevlilerinin meslekî bilgi ve beceri açısından kendilerini yeterli görüp görmemelerinin meslekî doyum üzerindeki etkisi incelenmiştir. Yapılan istatistiksel işlemde, mesleki doyum düzeyinin mesleki bilgi ve beceri açısından yeterli olma durumuna göre anlamlı farklılık gösterip göstermediğini test eden $\mathrm{F}$ testi sonucuna göre anlamlılık değeri $\mathrm{p}<0,05$ bulunmuştur. Bu değere göre ortalamalar arasında anlamlı fark vardır. Yani, mesleki doyum düzeyi mesleki bilgi ve beceri açısından yeterli olma durumuna göre anlamlı farklılık gösterir.

Tablo 10. Mesleki Doyum Düzeyinin Meslekten Duyulan Memnuniyete Göre Farklılı̆̆ını İnceleyen T Testi Sonuçları

\begin{tabular}{llccccc}
\hline \multirow{2}{*}{ Ölçek/Boyutlar } & $\begin{array}{l}\text { Meslekten } \\
\text { Memnuniyet }\end{array}$ & $\begin{array}{c}\text { Kişi } \\
\text { Sayısı }\end{array}$ & $\overline{\boldsymbol{X}}$ & $\begin{array}{c}\text { Std. } \\
\text { Sapma }\end{array}$ & \multirow{2}{*}{$\mathbf{t}$} & $\mathbf{p}$ \\
\hline \multirow{2}{*}{ Mesleki Doyum } & Evet & 382 & 92.54 & 10.896 & \multirow{2}{*}{$66.724^{*}$} & 0,001 \\
& Kismen & 33 & 74.73 & 8.183 & & \\
\hline
\end{tabular}

${ }^{*} \mathrm{p}<0,05$

Mesleki doyum düzeyinin meslekten duyulan memnuniyete göre anlamlı farklılık gösterip göstermediğini test eden $t$ testi sonucuna göre anlamlılık değeri $\mathrm{p}<0,05$ bulunmuştur. Bu değere göre ortalamalar arasında anlamlı fark vardır. Yani, mesleki doyum düzeyi meslekten duyulan 
memnuniyet durumuna göre anlamlı farklılık gösterir. Mesleğinden kısmen memnun olanların mesleki doyum düzeyi mesleğinden memnun olanlara göre oldukça düşük düzeydedir.

Tablo 11. Mesleki Doyum Düzeyinin Mesleği Severek Yapma Durumuna Göre Farklılı̆̆ını İnceleyen T Testi Sonuçları

\begin{tabular}{llccccc}
\hline $\begin{array}{c}\text { Ölçek/Boyut- } \\
\text { lar }\end{array}$ & $\begin{array}{l}\text { Mesleği } \\
\text { Severek } \\
\text { Yapma }\end{array}$ & $\begin{array}{c}\text { Kişi } \\
\text { Sayısı }\end{array}$ & $\overline{\boldsymbol{X}}$ & $\begin{array}{c}\text { Std. } \\
\text { Sapma }\end{array}$ & $\mathbf{t}$ & $\mathbf{p}$ \\
\hline Mesleki Do- & Evet & 392 & 92.06 & 11.246 & \multirow{2}{*}{$44.686^{*}$} & 0.001 \\
yum & Kismen & 24 & 74.17 & 9.545 & \\
\hline
\end{tabular}

${ }^{*} \mathrm{p}<0,05$

Mesleki doyum düzeyinin mesleği severek yapma durumuna göre anlamlı farklılık gösterip göstermediğini test eden $t$ testi sonucuna göre anlamlılık değeri $\mathrm{p}<0,05$ bulunmuştur. Bu değere göre ortalamalar arasında anlamlı fark vardır. Yani, mesleki doyum düzeyi mesleği severek yapma durumuna göre anlamlı farklılık gösterir. Mesleğini kısmen severek yapanların mesleki doyum düzeyi mesleğini tamamen severek yapanlara göre oldukça düşük düzeydedir.

Tablo 12. Mesleki Doyum Düzeyinin Uygun Şartlar Oluşması Durumunda Mesleği Bırakma Durumuna Göre Farklılığını Inceleyen F Testi Sonuçlan

\begin{tabular}{llccccc}
\hline Ölçek/Boyutlar & $\begin{array}{l}\text { Görevi } \\
\text { Birakma }\end{array}$ & $\begin{array}{c}\text { Kişi } \\
\text { Sayıs }\end{array}$ & $\overline{\boldsymbol{X}}$ & $\begin{array}{c}\text { Std. } \\
\text { Sapma }\end{array}$ & F & p \\
\hline \multirow{3}{*}{ Mesleki Doyum } & Evet & 43 & 75.56 & 12.990 & & \\
& Hayır & 327 & 93.91 & 10.050 & $71.406^{*}$ & 0.001 \\
& Kararsızım & 49 & 83.12 & 11.847 & & \\
\hline
\end{tabular}

${ }^{*} \mathrm{p}<0,05$

Mesleki doyum düzeyinin uygun şartların olması durumunda mesleği bırakma durumuna göre anlamlı farklılık gösterip göstermediğini test eden $F$ testi sonucuna göre anlamlılık değeri $p<0,05$ bulunmuştur. Bu değere göre ortalamalar arasında anlamlı fark vardır. Yani, mesleki doyum düzeyi uygun şartların olması durumunda mesleği bırakma durumuna göre anlamlı farklılık gösterir. Uygun şartların oluşması durumunda mesleğini bırakabileceğini belirtenlerin mesleki doyum düzeyi diğerlerine göre daha düşük düzeydedir. 


\section{Tartışma}

Bu araştırmada, Bilecik il merkezi, ilçe merkezi, kasaba ve köylerde görev yapan din görevlilerinin meslekle ilgili bir takım algılamalarının meslekî doyum düzeylerine etkisi incelenmiştir.

Araştırmada elde edilen bulgular incelendiğinde, araştırmaya katılanların \%59,7'si İmam-Hatip (Kadrolu, Sözleşmeli, Vekil), \%28'i Kur'an Kursu Öğreticisi (Kadrolu, Sözleşmeli, Fahri), \%12,4'ü Müezzin-Kayyım olarak görev yapmakta olan din görevlilerinden oluşmakta olduğu görülmektedir. Araştırmaya katılanların \%3,6'sı görev yaptığ 1 yerden hiç memnun değilken, \%32'si biraz memnun ve \%64,4'ü de çok memnun olduğunu; \%91,2'si çalıştığı meslekten memnunken, \%7,9'u kısmen memnun olduğunu, \%1'i de memnun olmadığını; \%93,6'sı mesleğini severek yaptığını belirtirken, \%0,7'si mesleğini sevmeden yaptığını, \%5,7'si de kısmen severek yaptığını; \%15'i mesleki bilgi ve beceri açısından kendisini tamamen yeterli görürken, \%54,2'si yeterli, $\% 28,6$ 's1 kısmen yeterli, $\% 2,1^{\prime} \mathrm{i}$ ise yetersiz gördüğünü; \%10,3'ü koşulların uygun olması durumunda mesleğini bırakıp başka kurumda çalışmayı isterken, \%78'si ise hangi koşullarda olursa olsun sahip olduğu mesleği bırakıp başka bir mesleğe geçmeyi düşünmediğini, \%11,7'si ise bu kararsız olduklarını belirtmişlerdir.

Din görevlilerinin meslekle ilgili bir takım algılamalarını ifade eden bazı değişkenler ile meslekî doyum düzeyleri arasındaki karşılıklı ilişkiyi tespit etmeye yönelik yapılan analizlere bakıldığında ise; mesleki doyum düzeyinin görev yapılan yerden duyulan memnuniyete göre anlamlı farklılık gösterip göstermediğini test eden $F$ testi sonucuna göre anlamlılık değeri $p<0,05$ bulunmuştur. Bu değere göre ortalamalar arasında anlamlı fark vardır. Yani, mesleki doyum düzeyi görev yerinden memnuniyet durumuna göre anlamlı farklılık gösterir. Görev yerinden hiç memnun olmayan ve biraz memnun olanların mesleki doyum düzeyi görev yerinden memnun olanlara göre oldukça düşük düzeydedir. Bu sonuçlar, literatürde yer alan bazı araştırma sonuçlarıyla paralellik arz etmektedir. Örneğin, Mersin (2007) çalışmasında, din görevlilerinin görev yaptıkları yerin meslekî doyumları üzerinde etkili olduğu sonucuna ulaşırken, Yıldız da $(1999,184)$, yaptığı araştırmada, din görevlilerinin görev alanlarının mesleki tatmin üzerinde etkili olduğu bulgusuna ulaşmıştır. 
Araştırmada din görevlilerinin meslekî bilgi ve beceri açısından kendilerini yeterli görüp görmemelerinin meslekî doyum üzerindeki etkisi incelenmiştir. Yapılan istatistiksel işlemde, mesleki doyum düzeyinin mesleki bilgi ve beceri açısından yeterli olma durumuna göre anlamlı farklılık gösterip göstermediğini test eden $\mathrm{F}$ testi sonucuna göre anlamlılık değeri $\mathrm{p}<0,05$ bulunmuştur. Bu değere göre ortalamalar arasında anlamlı fark vardır. Yani, mesleki doyum düzeyi mesleki bilgi ve beceri açısından yeterli olma durumuna göre anlamlı farklılık gösterir. Mesleki bilgi ve beceri açısından yeterli olduğunu belirtenlerin mesleki doyum düzeyi daha yüksek düzeydedir. Buradan hareketle, ankete katılan din görevlilerinin yapmakta oldukları iş açısından meslekî bilgi ve beceri yeterliliklerinin, meslekî doyum puanları üzerinde istatistiksel olarak anlamlı bir etkisinin olduğunu söylemek mümkündür.

İşten memnuniyet, o işte başarının en öncül koşullarından biridir. Bireyin işine karşı olumsuz tutumunun oluşması sonucunda mesleki doyumu azalır. Doyumsuz birey genellikle başka arayışlar içerisinde olacaktır. Din görevlileri başta hizmet verdikleri kitle olarak cemaat ve görev bölgesinde yaşayan insanlarla sürekli ilişki halindedirler (Çekin, 2005). Din görevlilerinin bu mesleği icra ederken karşılaştıkları çok çeşitli sıkıntıları olabilmektedir. Din görevlilerinin mesleki doyumlarını etkileyen olumsuzluklar zaman zaman daha ileri problemlerin ortaya çıkmasına da neden olabilmektedir. Bu da din görevlilerinin farklı iş alanlarında ve kurumlarda kendi yaşam algı ve biçimlerine uygun bir pozisyon oluştuğunda mesleği terk etmeleri durumudur (Buyrukçu, 1995). Bu bağlamda aşağıdaki tabloda din görevlilerinin mesleki doyum düzeylerinin, uygun şartların olması durumunda mesleği bırakma durumuna göre ilişkisine yönelik elde edilen bulgular paylaşılmıştır.

\section{Sonuç ve Öneriler}

Araştırmada şu sonuçlara ulaşılmıştır:

- Din görevlilerinin mesleki doyum düzeylerinin; yapılan meslekten ve görev yapılan yerden duyulan memnuniyet, mesleği severek yapma, mesleki bilgi ve beceri açısından yeterli olma ve uygun 
şartların olması durumunda mesleği bırakma durumlarına göre anlamlılık değerlerinin $\mathrm{p}<0,05$ olup;

- Mesleğinden ve görev yerinden memnuniyetin mesleki doyumunu, memnuniyetsizliğin mesleki doyumsuzluğunu artırıcı bir etkisinin olduğu, mesleğinden ve görev yerinden hiç memnun olmayan ve kısmen memnun olanların mesleki doyum düzeylerinin görev yerinden memnun olanlara göre oldukça düşük düzeyde olduğu,

- Mesleği severek yapmanın mesleki doyumunu olumlu yönde etki ettiği, mesleğini kısmen severek yapanların mesleki doyum düzeylerinin mesleğini tamamen severek yapanlara göre oldukça düşük düzeyde olduğu,

- Mesleği ile ilgili bilgi ve beceri açısından yeterli olmanın mesleki doyumunu artırıcı, bilgi eksikliğinin mesleki doyumsuzluğunun artmasına sebebiyet verdiği, mesleki bilgi ve beceri açısından yeterli olduğunu belirtenlerin mesleki doyum düzeyinin mesleki bilgi ve beceri açısından kendilerinin az yeterli ve yetersiz olduğunu belirtenlere göre daha yüksek düzeyde olduğu ve uygun şartların oluşması durumunda mesleğini bırakabileceğini belirtenlerin mesleki doyum düzeylerinin diğerlerine göre daha düşük düzeyde olduğu tespit edilmiştir.

Elde edilen bu sonuçlara göre şu önerilerde bulunulabilir:

- Diyanet İşleri Başkanlığı, hizmet içi eğitimler ile personelinin bilgi ve beceri açısından yeterli seviyeye ulaşmasını,

- Personele kapasitelerinin altında veya çok üzerinde bir iş yüküne maruz bırakmayarak mesleğini severek ve isteyerek yapmasının teminini,

- Görevde yükselme sınavları ve kariyer olanakları ile nitelikli personelin istihdam edilmesi ve kurum içinde tutulmasını,

- Belirli zaman sınırlaması ile rotasyon gerçekleştirmek suretiyle de görev yeri memnuniyetsizliğinin ortadan kaldırılmasını sağlayacak girişimlerde bulunarak personelin mesleki doyumunun artışına ve böylece hizmet kalitesinin artmasına katkı sunacağı kanaatine varılmıştır. 


\title{
EXTENDED ABSTRACT
}

\section{A Research on the Occupational Job Satisfaction of Religious Officers}

\author{
Emre Yilmaz \\ Zonguldak Bülent Ecevit University
}

This study, the Presidency of Religious Affairs Bilecik Provincial and district mufti within the headquarters, towns and villages Imam-Hatip, Müezzin-Kayyim and the Qur'an as a teacher of the duties of the religious officials who served in the profession and the task places, whether or not to do the job, The aim of this study is to provide a descriptive study to determine the relationship between the levels of occupational satisfaction and the variables related to the profession, such as whether they are sufficient in terms of professional knowledge and skills, and in case of appropriate conditions, whether to abandon the profession or not.

\section{Materials and Method}

Relational screening model was used in the study. This research is in the screening model because it tries to determine some variables related to occupational perceptions of religious officials and the levels of vocational satisfaction. However, the research is also in the relational model because it examines the relationship between the levels of professions' professions and the levels of vocational satisfaction.

\section{Universe and Sample}

A total of 465 religious officials, who were serving as permanent, contracted and honorary status teachers of Imam-Hatip, Müezzin Kayyim and Qur'an Courses in the centers, villages and towns of Bilecik, formed the universe of the research. The sample of the study was composed of 433 
religious officials who were present at the meetings except for the personnel who did not attend the monthly meetings held in August, September, October and November.

\section{Research Hypotheses}

- The level of professional satisfaction of the personnel working in the religious services class in the Presidency of Religious Affairs differs significantly from the level of satisfaction with the profession. Those who are partially satisfied with their profession have a very low level of professional satisfaction compared to those who are satisfied with their profession.

- The level of professional satisfaction differs significantly from job satisfaction. The level of professional satisfaction of those who are not satisfied with their positions and who are slightly satisfied is quite low compared to those who are satisfied with their positions.

- The level of professional satisfaction differs significantly from the level of professional knowledge and skills. The level of professional satisfaction of those who say that they are sufficient in terms of professional knowledge and skills is at a higher level in terms of professional knowledge and skills than the ones that stated that they are insufficient and inadequate.

- The level of professional satisfaction differs significantly according to the profession. The level of professional satisfaction of those who partially like to do their job is quite low compared to those who love their profession completely.

- The level of professional satisfaction differs significantly in case of suitable conditions. The level of occupational satisfaction of the students who stated that they can leave their profession in the case of proper conditions is lower than the others.

\section{Conclusion}

The following results were obtained in the research: 
- Professional satisfaction levels of religious officials; the satisfaction of the profession and the place of duty, the profession of doing the job, the professional knowledge and skills in terms of being adequate and in the case of appropriate conditions, according to the status of the occupation of the significance values of $\mathrm{p}<0.05$;

- Satisfaction of the profession and the job satisfaction of the job satisfaction, dissatisfaction, there is an effect enhancing the professional dissatisfaction, the profession and the job satisfaction and partly satisfied with the job satisfaction levels of those who are very satisfied with the job place is very low level,

- The job satisfaction level has a positive effect on the job satisfaction and the job satisfaction level of those who love the job is very low compared to those who love the profession.

- The level of professional satisfaction and the level of professional satisfaction in terms of professional knowledge and skills are higher than the ones who stated that they are sufficient and insufficient in terms of their professional knowledge and skills. and that the occupational satisfaction levels of those who stated that they could leave their profession in the case of appropriate conditions were found to be lower than the others.

\section{Kaynakça / References}

Balcı, A. (2015). Sosyal bilimlerde araştırma yöntem, teknik ve ilkeler. Ankara: Pegem Akademi Yayınları.

Buyrukçu, R. (2005). Din görevlisinin mesleğini temsil gücü. Ankara: Türkiye Diyanet Vakfı Yayınları.

Büyüköztürk, Ş. (2008). Bilimsel araştırma yöntemleri. Ankara: Pegem Akademi Yayınları.

Çekin, A. (2005). "Meslekî ve sosyal boyutlarıyla yurtdışı din görevliliği", III. Din şûrâsı tebliğ ve müzakereleri. Ankara: Diyanet İşleri Başkanlığı Yayınları, ss. 214-232.

Karasar, N. (2005). Bilimsel araştırma yöntemi. Ankara: Nobel Yayınları. 
Kayıklık H. (2008). “Din görevlilerinde yaşamdan memnuniyet ve meslekî doyum (Adana Örneği)", I. Din Hizmetleri Sempozyumu, Ankara: Diyanet İşleri Başkanlığı Yayınları, C. 1, ss. 34-46.

Kuzgun Y., Sevim, S. A. ve Hamamcı Z. (2005). Mesleki Doyum Ölçeği, Pdr'de Kullanılan Ölçekler, Ed. Y. Kuzgun, F. Bacanlı. Ankara: Nobel Yayın Dağıtım, ss. 82-87.

Kuzgun Y. ve Bacanlı, F. (2005). Pdr'de Kullanılan Ölçekler, Nobel Yayın Dağıtım, C.1, ss.84-85, Ankara.

Mersin, Y. (2007). Din görevlilerinde meslekî doyum. (Yayımlanmamış Yüksek Lisans Tezi), Selçuk Üniversitesi Sosyal Bilimler Enstitüsü Konya.

Özdemir E. (2014). “Tarama yöntemi”, M. Metin. (Ed.) Kuramdan Uygulamaya Ĕ̆itimde Bilimsel Araştırma Yöntemleri, Ankara: Pegem Akademi Yayınları.

Piyal, B., Piyal, B., Yavuz, İ. ve Yavuz, A. (2002). Sosyal sigortalar kurumu Ankara eğitim hastanesinde çalışanların iş doyumu etkileyen etmenler.Kriz Dergisi, 10(1), 45-56.

Yelboğa, A. (2008). İnsan kaynakları bölümünde çalışanların iş doyumlarındaki farkl1lıkların incelenmesi. Yönetim, 19(61), 125-142.

Yıldız M. C. (1999). Din görevlilerinin sorunları ve beklentileri üzerine sosyolojik bir araştırma: Elazı̆̆ uygulaması. Yayınlanmamış Doktora Tezi, Frrat Üniversitesi, Sosyal Bilimler Enstitüsü, Elazığ.

\section{Kaynakça Bilgisi / Citation Information}

Yılmaz, E. (2019). Din görevlilerinin mesleki doyum düzeyleri üzerine bir araştırma. OPUS-Uluslararası Toplum Araştırmaları Dergisi, 10(17), 104-122. DOI: 10.26466/opus.520597 